(UDC: 532.517 .2$)$

\title{
A computational study of trajectories of micro- and nano-particles with different shapes in flow through small channels
}

\author{
V. Isailovic ${ }^{1}$, M. Kojic ${ }^{1,2,3 *}$, M. Milosevic ${ }^{2}$, N. Filipovic ${ }^{1,4}$, N. Kojic ${ }^{5}$, A. Ziemys ${ }^{2}$, M. \\ Ferrari $^{2}$ \\ ${ }^{1}$ Belgrade Metropolitan University - Research and Development Center for Bioengineering \\ BioIRC, Kragujevac, Serbia \\ velibor@kg.ac.rs \\ ${ }^{2}$ The Houston Methodist Research Institute, Houston, TX, USA \\ mkojic42@gmail.com \\ ${ }^{3}$ Serbian Academy of Sciences and Arts, Belgrade, Serbia \\ mkojic42@gmail.com \\ ${ }^{4}$ Faculty of Technical Sciences, University of Kragujevac, Kragujevac, Serbia \\ fica@ kg.ac.rs \\ ${ }^{5}$ Center for Engineering in Medicine and Surgical Services, Massachusetts General Hospital, \\ Harvard Medical School, Boston, USA \\ * Corresponding author mkojic42@gmail.com
}

\begin{abstract}
Transport of small particles, of micrometer and sub-micrometer size, by fluid occurs in many technological and biological systems. The channels through which the fluid flows are often with cross-sectional dimensions on the order of several to tens of micrometers. The aim of this study was to investigate effects of shape of micro- and nano-particles on particle trajectories when particles are transported within small channels as blood vessels. Efficiency of therapeutics by particles as the drug carriers is significantly dependent on particle trajectories. It is desirable to have particle trajectories approaching the vessel walls in order to increase therapeutic efficacy. We studied motion of particles in channels (pipes) for two physical conditions: Poiseuille flow, which is characteristic in pipe flow, and shear flow. Shear flow conditions are analyzed since the character of fluid flow near the wall in these systems can be approximated as shear, with a linear change of velocity with the distance from the wall. We here investigated trajectories of particles of different shapes in 2D flow using the finite element (FE) method, with a strong coupling approach for solid-fluid interaction and a remeshing procedure. The results give insight into the characteristics of the particle motion, e.g. trajectories and rotations, under various flow conditions in micron size channels, including flow in the presence of moving deformable discs. We demonstrate that the particle trajectories are essentially parallel to the wall for various conditions and that particle size and shape do not considerably alter the parallel nature of the trajectories.
\end{abstract}

Keywords: solid-fluid interaction, particle motion, Poiseuille flow, shear flow, microchannels, small blood vessels, finite element method 


\section{Introduction}

Generally, considering particle transport by fluid, it can be found that in many technological solutions, particle transport represents a fundamental process (Patankar et al. 2001). For example, using suspensions of particles it is possible to economically transport solid particulate material in industry, such as pulp handling in paper manufacturing or petroleum processing in fluidized beds, or in powder technology ( $\mathrm{Ng}$ et al. 2007).

Also, convective transport of small particles in biological systems is present and has an important role in organ functioning and therapeutics (Adriani et al. 2012, Decuzzi et al. 2005, Ferrari 2005, Gentile et al. 2008, Gutfinger et al. 1998, Lee et al. 2009). In particle transport, the accumulation of particles on the surrounding walls is of particular interest in nanotherapeutics.

Besides experimental investigations, significant research efforts have been devoted to find appropriate methods of mathematical modeling of particle motion. We cite several of these methods. The so-called Stokes dynamics assumes evaluation of forces and torques acting on particles using the Stokes fluid model and neglecting effects of motion of particles on fluid flow (Freeman 1985, Jayageeth et al. 2009, Nott and Brady 1994, Singh and Nott 2000). Direct numerical simulation (DNS) for fluid and neglecting the influence of particle motion on fluid was presented in (You et al. 2004). Several methods have been introduced where solutions were obtained by coupling particle motion and fluid flow, among which we here cite several concepts, such as integral equation for particle motion and the boundary element method (Pozrikidis 2006a, Pozrikidis 2006b); fictitious domain approach (Glowinski et al. 2001, Goano et al. 2003); arbitrary Lagrangian-Eulerian (ALE) formulation (Hu et al. 2001); Lattice Boltzmann method (Feng and Michaelides 2003); Lagrange multiplier method (Glowinski, Pan, Hesla, Joseph and Periaux 2001, Singh et al. 2003); immerse boundary finite element method (Adriani, Tullio, Ferrari, Hussain, Pascazio, Liu and Decuzzi 2012, Zhang et al. 2004); finite element method with remeshing in an explicit-implicit procedure called direct simulation (Hu et al. 1992). We employ a strong coupling approach using remeshing and an implicit incremental-iterative scheme.

Determination of the lift (or lateral) force appearing when particles are transported by fluid is given in a number studies. There, detailed analyses have been carried out to elucidate the physics and origin of this force (Asmolov 1999, Chun and Ladda 2006, Matas et al. 2004, Matas et al. 2009), together with experimental validation (Matas, Morris and Guazzelli 2004). It was found that for large Re numbers, a phenomenon called inertial focusing occurs, i.e. particles reach a final position where the lateral force becomes equal to zero and particles travel parallel to the wall of pipe or channel, independently from their initial position. This phenomenon is particularly explored in design of microchip devices used in cell biology (Carlo, Irimia, Tompkins and Toner 2007, Zhou and Papautsky 2013).

Following general engineering, and particularly bioengineering interests related to research in nanoparticle drug delivery (Adriani, Tullio, Ferrari, Hussain, Pascazio, Liu and Decuzzi 2012, Decuzzi, Lee, Bhushan and Ferrari 2005, Ferrari 2005, Gentile, Chiappini, Fine, Bhavane, Peluccio, Cheng, Liu, Ferrari and Decuzzi 2008), in this report we consider the motion of micron- and nano-size rigid particles of various shapes in 2D Poiseuille flow and shear. Also, in the case of Poiseuille flow we include motion of deformable particles. Our aim is mainly to investigate the effects of particle shape on particle trajectories for these two cases of fluid flow. Our focus is to bring more information regarding the effects of particle shape on trajectories, besides the existing results as in (Decuzzi, Lee, Bhushan and Ferrari 2005, Gavze and Shapiro 1998).

We have shown that the presented FE methodology and software (Kojic et al. 1998, 2009) are robust, by comparing the results with those available in literature, and with validation through our experimental findings. 


\section{Finite element model with remeshing procedure}

Here, we summarize the basic equations and remeshing procedure used in our analysis. NavierStokes equations represent the balance of linear momentum, and in the case of a Newtonian fluid they can be written in the form (Kojic et al. 2008)

$$
\rho_{f}\left(\frac{\partial v_{i}}{\partial t}+\frac{\partial v_{i}}{\partial x_{k}} v_{k}\right)=-\frac{\partial p}{\partial x_{i}}+\mu \frac{\partial^{2} v_{i}}{\partial x_{k} \partial x_{k}}+f_{i}^{V} \quad i=1,2,3 ; \text { sumon } k: k=1,2,3
$$

where $v_{i}$ are fluid velocities, $p$ is pressure, $f_{i}^{V}$ are volumetric forces; and $\rho_{f}$ and $\mu$ are fluid density and dynamic viscosity. If inertial terms are neglected (on the left-hand side), these equations reduce to the known Stokes equations (or Stokes model),

$$
-\frac{\partial p}{\partial x_{i}}+\mu \frac{\partial^{2} v_{i}}{\partial x_{k} \partial x_{k}}+f_{i}^{V}=0 \quad i=1,2,3 ; \quad \text { sumon } k: k=1,2,3
$$

Besides these, the continuity equation for incompressible fluid must be satisfied:

$$
\frac{\partial v_{i}}{\partial x_{i}} \equiv \frac{\partial v_{x}}{\partial x}+\frac{\partial v_{y}}{\partial y}+\frac{\partial v_{z}}{\partial z}=0
$$

The above equations can be transformed into a so-called weak form of balance equations using a weighted procedure (Galerkin method (Kojic, Filipovic, Stojanovic and Kojic 2008)). For the Navier-Stokes model, the incremental-iterative matrix form of balance equations for a time step $n$ of size $\Delta t$, which include the continuity equation (3), can be written in the form:

$$
\begin{aligned}
& {\left[\begin{array}{cc}
\frac{1}{\Delta t} \mathbf{M}+\tilde{\mathbf{K}}_{v v}{ }^{(i-1)} & \mathbf{K}_{v p} \\
\mathbf{K}_{v p}^{T} & \mathbf{0}
\end{array}\right]\left\{\begin{array}{c}
\Delta \mathbf{V}^{(i)} \\
\Delta \mathbf{P}^{(i)}
\end{array}\right\}=} \\
& \left\{\begin{array}{c}
\mathbf{F}_{x x t}^{(i-1)} \\
0
\end{array}\right\}-\left[\begin{array}{cc}
\frac{1}{\Delta t} \mathbf{M}+\mathbf{K}_{v v}{ }^{(i-1)} & \mathbf{K}_{v p} \\
\mathbf{K}_{v p}^{T} & 0
\end{array}\right]\left\{\begin{array}{l}
\mathbf{V}^{(i-1)} \\
\mathbf{P}^{(i-1)}
\end{array}\right\}+\left\{\begin{array}{c}
\frac{1}{\Delta t} \mathbf{M} \mathbf{V}^{n} \\
0
\end{array}\right\}
\end{aligned}
$$

where matrix $\mathbf{M}$ corresponds to the local velocity derivatives $\partial v_{i} / \partial t$; matrices $\tilde{\mathbf{K}}_{v v}{ }^{(i-1)}$ and $\mathbf{K}_{v v}{ }^{(i-1)}$ include convective velocity derivatives $\frac{\partial v_{i}}{\partial x_{k}} v_{k}$ and viscous terms; $\mathbf{K}_{v p}$ is the matrix coupling velocities and pressure; $\mathbf{F}_{\text {ext }}$ are external nodal forces corresponding to volumetric forces and action of the surrounding elements; $\mathbf{V}$ and $\mathbf{P}$ are nodal velocity and pressure vectors ( $\mathbf{V}^{n}$ is velocity at start of time step); and the right upper indices $i$ and $i-1$ denote the current and previous equilibrium iteration within time step. The time integration procedure is implicit, hence the overall system of balance equations is satisfied at the end of time step, and iterations continue until selected convergence criteria are satisfied. Details about matrices and computations are given elsewhere (Kojic, Filipovic, Stojanovic and Kojic 2008).

Moving particles are modeled using a separate mesh for each particle. Balance equations of a solid finite element are based on Newton's law and can be written in the form

$$
\left(\frac{1}{\Delta t} \mathbf{M}^{s}+\Delta t \mathbf{K}^{s(i-1)}\right) \Delta \mathbf{V}^{s}=\mathbf{F}_{e x t}^{s(i-1)}-\mathbf{F}_{\mathrm{int}}^{s(i-1)}-\frac{1}{\Delta t} \mathbf{M}^{s}\left(\mathbf{V}^{s(i-1)}-\mathbf{V}^{s n}\right)
$$


where $\mathbf{M}^{s}$ and $\mathbf{K}^{s}$ are the mass and stiffness matrix of the solid, $\mathbf{V}^{s}$ is the nodal velocity vector $\left(\mathbf{V}^{s n}\right.$ is velocity at start of time step); $\mathbf{F}_{\text {ext }}^{s}$ are external nodal forces which include volumetric forces, and nodal forces from other elements - together with forces from fluid elements for common solid-fluid nodes; and $\mathbf{F}_{\text {int }}^{s}$ are internal nodal forces arising from stresses within solid (we here use the total Lagrangian formulation) (Bathe 1996, Kojic and Bathe 2005). Note that we use the term $\Delta t \mathbf{K}^{s(i-1)}$ for better convergence (it does not affect the solution which only depends on the right-hand side of equation (5)).

We use a remeshing procedure (Kojic et al. 2011) which assumes that the surface nodes of the particle mesh and of the fluid are the same for the current step, hence these nodes have the same velocities. When convergence is reached, we displace all solid nodes for $\Delta \mathbf{U}^{s}=\Delta t \mathbf{V}^{s}$ (graphically shown in Fig. 1). Then, we generate a new fluid mesh for the next time step, with common nodes at the displaced solid surface nodes. Besides a purely geometrical change in the mesh, it is necessary to project solutions from the previous mesh to the new mesh. We search over all new fluid nodes, find the element in the previous mesh to which each node belongs, and use isoparametric interpolation from the element nodes to find the velocity and pressure at the new node.

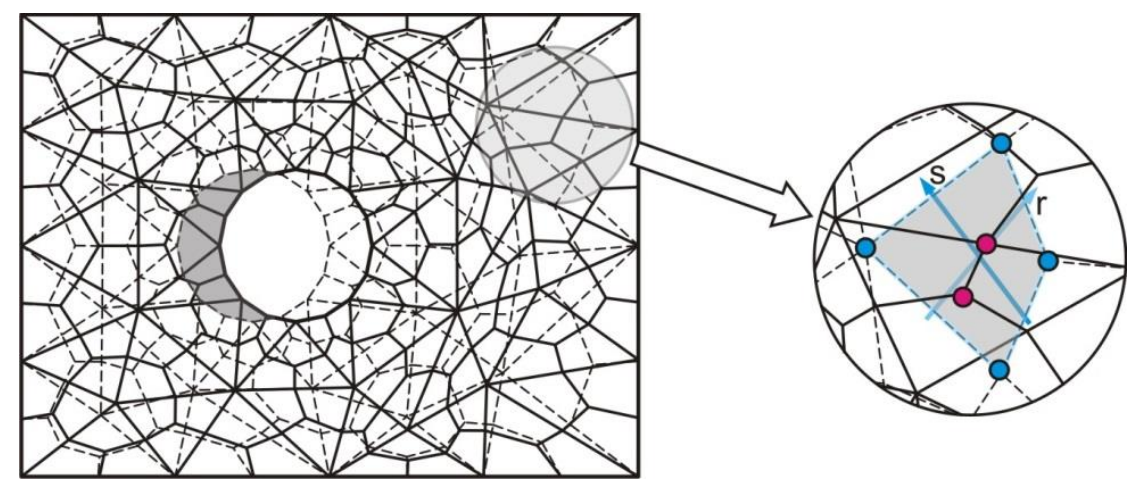

Fig. 1. Schematics of the remeshing procedure. After the solution for the current time-step is obtained, the solid is displaced, a new fluid mesh is generated (with common solid and fluid nodes at the solid surface), and solutions from the old mesh are mapped to the new mesh (Isailovic 2012).

We have implemented the above described methodology into our FE program PAK-FS (Kojic, Filipovic, Slavkovic, Zivkovic and Grujovic 1998, 2009). Details of this methodology and its implementation are given in (Isailovic 2012). Solution accuracy of the methodology and software has been tested on various examples available in literature (Isailovic 2012)

\section{Results: Motion of rigid and deformable microparticles and nanoparticles in Poiseuille flow}

We here first consider a microchannel with an obstacle (resembling a plaque in a blood vessel) and then a microchannel with a narrowing through which two deformable discs flow together with nanoparticles. 


\subsection{Particles of various shapes in a microchannel with an obstacle}

Trajectories of particles of different shapes (Fig. 2b), in the channel shown in Fig. 2a, were calculated using our FE code PAK (Kojic, Filipovic, Slavkovic, Zivkovic and Grujovic 1998, 2009) and methodology described in Section 2.

We have found that all particles have trajectories nearly parallel to the wall, with some small deviations, but not with a tendency to approach or to go away with respect to the wall, even with large ratios $\mathrm{a} / \mathrm{b}$ (we used maximum $\mathrm{a} / \mathrm{b}=3$ ) for ellipse and rectangle. This is in agreement with experimental observation shown above. Values of the radius $\mathrm{R}$ were varied from 0.03 to 3 micrometers. Also, various initial positions were used, from very close to the wall (several nanometers), to the middle of the channel. As an illustration, we show in Fig. 3 trajectories of circular and polygonal particles.

a)

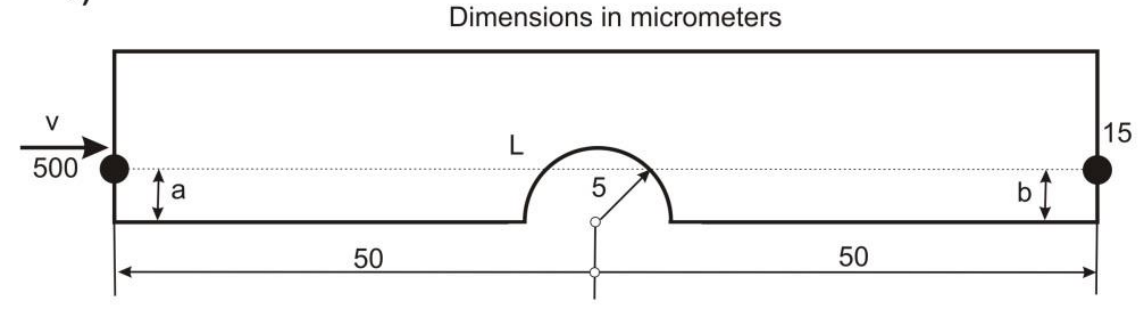

b) Particles:
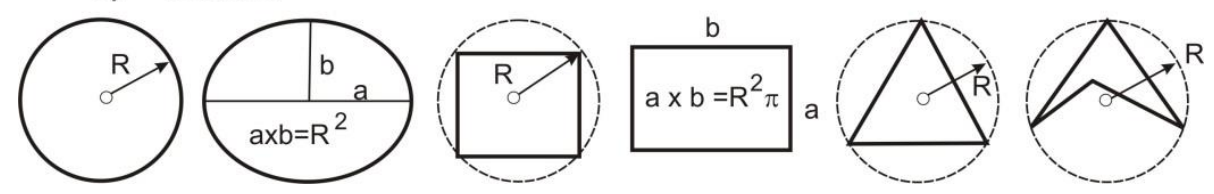

Fig. 2. Microchannel and particles carried by fluid. a) Dimensions of microchannel (entering velocity is $\mu m / s$. b) Shape of particles.

a)

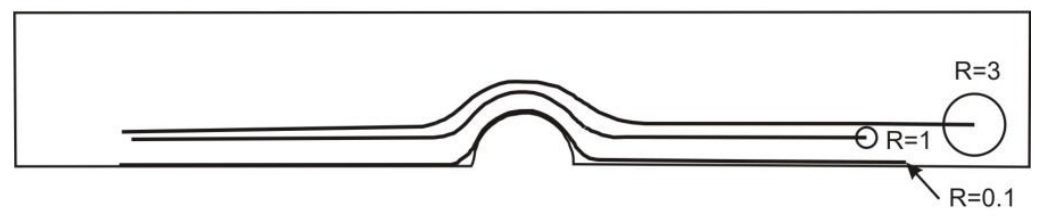

b)

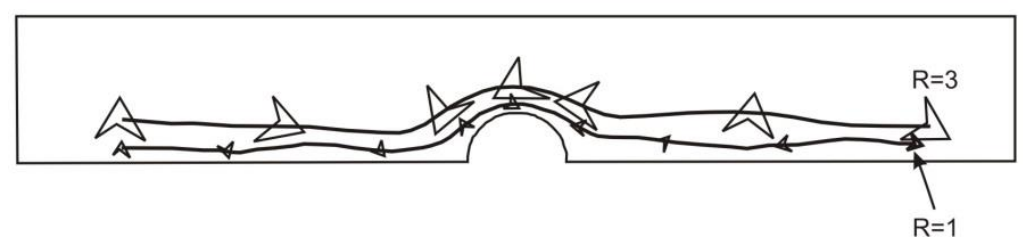

Fig. 3. Trajectories of particles in a channel with obstacle, with initial position close to the wall. a) Circular particles of three sizes (in micrometers). b) Polygonal shape particles. Trajectories are close to parallel to the wall, with some oscillations in case of a polygon; smaller particles rotate faster. 
3.2 Circular and elliptical particles in microchannel with narrowing and moving deformable discs

Here we consider trajectories of circular and elliptical nanoparticles within microchannel with narrowing and with moving deformable discs. Geometry of the microchannel, disc characteristics and nanoparticles were chosen to resemble a capillary blood vessel with blood flow, red blood cells and nanoparticles used for drug delivery (Decuzzi, Lee, Bhushan and Ferrari 2005, Ferrari 2005). Geometry of the channel is given in Fig. $4 \mathrm{a}$. Data for the discs are: diameter $=7 \mu \mathrm{m}$, initially $10 \mu \mathrm{m}$ from the entrance, symmetrically displaced with mutual distance of $3 \mu \mathrm{m}$; elastic material, with Young's modulus $E=200 P a$ and Poisson's ratio $v=0.49$; density $\rho_{s}=1.01 \cdot 10^{3} \mathrm{~kg} / \mathrm{m}^{3}$. Five nanoparticles which are rigid (elastic with $E=20000 P a$ ), with diameter of $200 \mathrm{~nm}$, initially at distance $2 \mu \mathrm{m}$ and displaced at equal distances from each other and the wall, are discretized by finite elements. Elliptical nanoparticles have the same area as the circular ones, with a ratio of semiaxes of 2:1. Solid-solid and solid-wall interactions are modeled by implementing fictitious line elements with appropriate stiffnesses (Isailovic 2012, Kojic et al. 2013).

a)

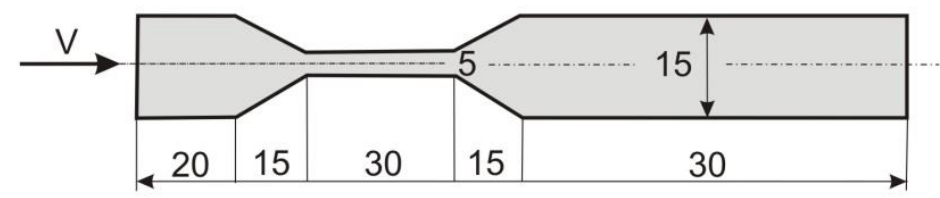

b)
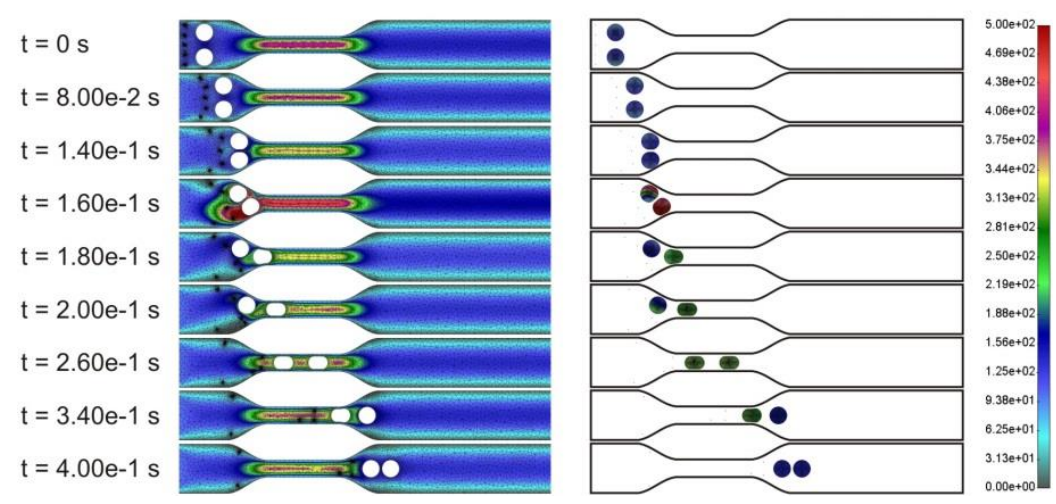

Fig. 4. Model of a channel with a narrowing. a) Geometry (dimensions in micrometers) and entering velocity $\mathrm{V}=100 \mu \mathrm{m} / \mathrm{s}$; b) Position of discs and velocity field for several time points

(Isailovic 2012).

Disc positions and the velocity field for several time points are shown in Fig. $4 \mathrm{~b}$. Additionally, positions of circular and elliptical nanoparticles at the moment when the first disk is entering the narrowing are shown in Fig. 5. The results indicate that the positions of circular and elliptical nanoparticles are the same. Figure 6 shows trajectories, while rotations are displayed in Fig. 7. Trajectories of circular and elliptical particles are essentially identical, whereas rotations differ considerably. 
The reported results in this section provide insight into the characteristics of motion of particles within a microchannel, which may be useful in microfluidics in general and particularly in bioengineering applications such as drug delivery.

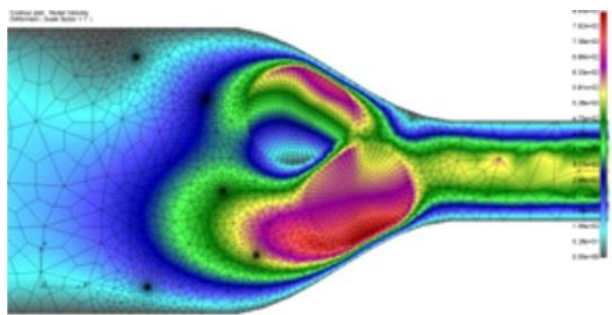

a)

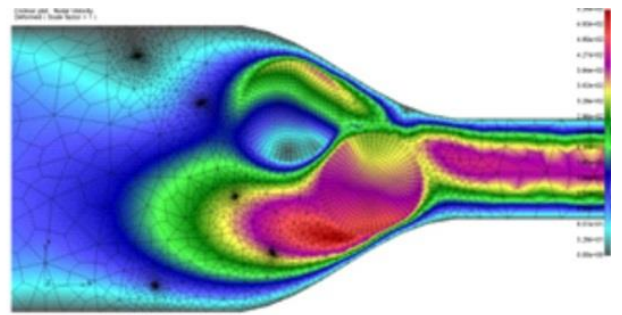

b)

Fig. 5. Position of circular (a) and elliptical (b) particles at the moment when the disc enters the narrowing.
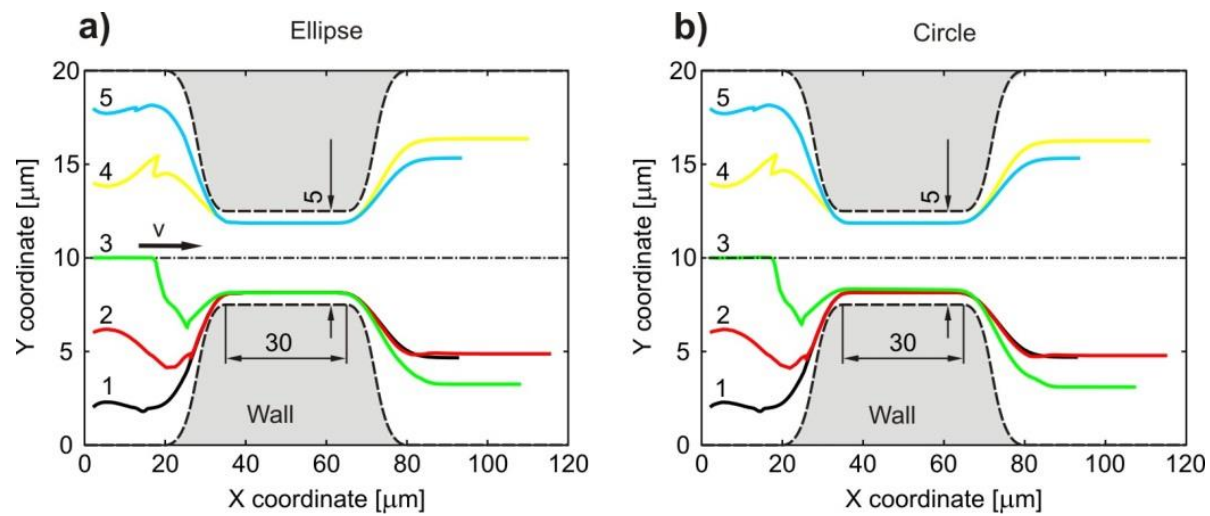

Fig. 6. Trajectories of nanoparticles in a channel with narrowing (dimensions as in Fig. 4a), with two deformable discs as in Fig. 4. a) Elliptical particles (semiaxes: $a=141.4 \mathrm{~nm}, \mathrm{~b}=70.7 \mathrm{~nm}$; b)

Circular particles (radius $\mathrm{R}=100 \mathrm{~nm}$ ).
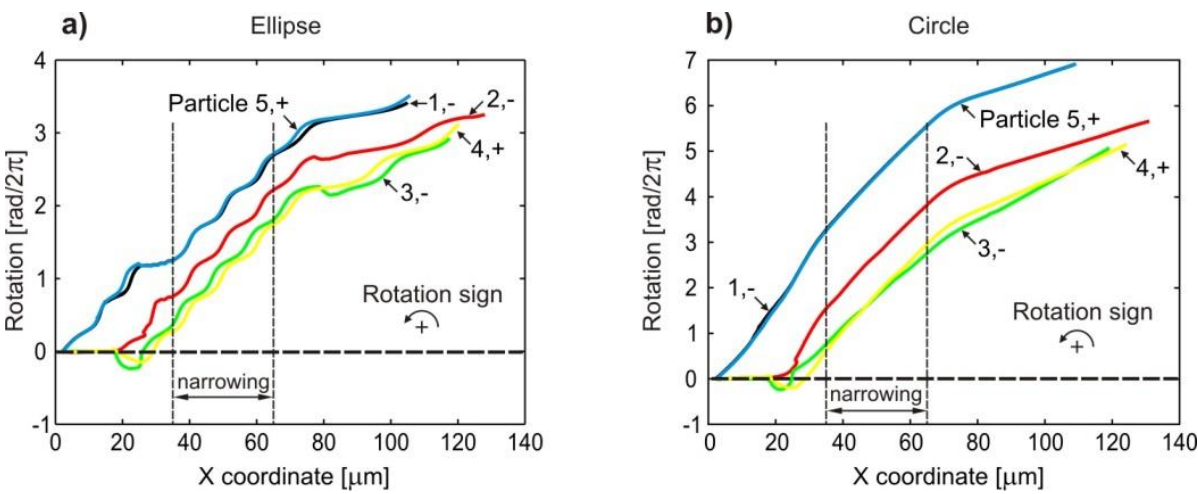

Fig. 7. Rotation of nanoparticles in a channel with narrowing, with two deformable discs as in Fig. 5. a) Elliptical particles; b) Circular particles. Data are given in Fig. 6. 


\section{Results: Motion of rigid micro- and nano-particles in shear flow}

In any laminar flow of an incompressible fluid through channels there is a domain near the wall where the velocity profile is close to linear and parallel to the wall. Therefore, it can be considered that near the wall flow has a character of shear or Couette flow. It is of interest to investigate motion of particles in shear flow within channels for technical and bioengineering applications. This investigation is also of interest for convective mass transport in biological systems, since attachment of particles and molecules to the wall depends on their trajectories near the wall surfaces. Particle trajectories of circular and elliptical shape in shear flow are analyzed here.

We first investigate motion of a micron size particle, starting from the same position, and adopting various shear rates. Data for the model are given in Fig. 8a and in the figure caption. The Stokes model for the fluid is assumed in order to compare our results with the previously published in literature. The fluid flow field with the FE mesh is shown in Fig. 8b, where a small disturbance of the flow is notable in the vicinity of the particle.

Trajectories of particles normalized with respect to the larger semiaxis c are shown in Fig. 8c. The trajectories have a wavy character, with a tendency of approaching the wall. The approach rate increases with increasing Stokes number, i.e. with increasing shear rate. This character for spheroidal particle trajectories is reported in (Gavze and Shapiro 1998) using an analytical method, and in (Lee, Ferrari and PaoloDecuzzi 2009) by applying a numerical procedure. However, if we use the same scale for both $\mathrm{x}$ and $\mathrm{y}$ axes, we obtain the true trajectories to be practically parallel to the wall, even for the largest Stokes number, as shown in Fig. 8d. Also, we calculated the slope of trajectories (calculated here as an average) and found that the maximum slope is $0.38 \mathrm{deg}$. for the maximum shear rate of $1.983 \mathrm{e}+8 \mathrm{~s}^{-1}$ (see Table in Fig. 8c). 
a)

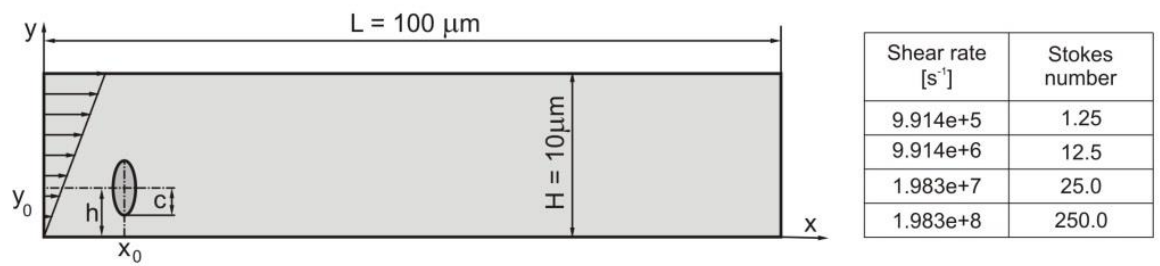

b)

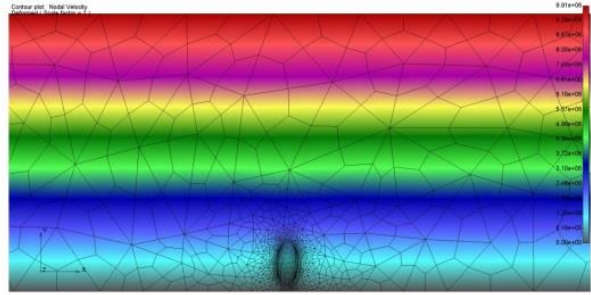

c)

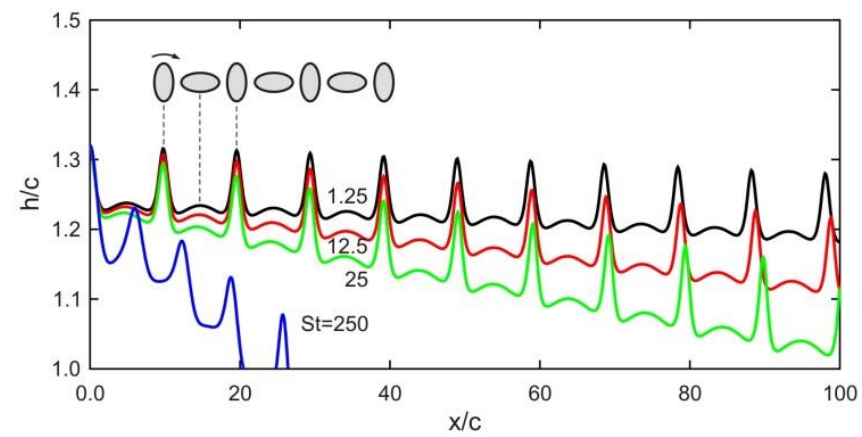

\begin{tabular}{|c|c|}
\hline Stokes number & Angle $\left[{ }^{\circ}\right]$ \\
\hline 1.25 & -0.0234 \\
\hline 12.5 & -0.0600 \\
\hline 25.0 & -0.1008 \\
\hline 250.0 & -0.3830 \\
\hline
\end{tabular}

d)

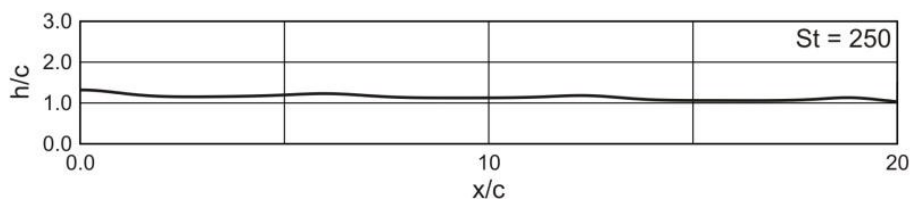

Fig. 8. Motion of elliptical microparticle in shear flow, Stokes model for fluid. a) Model data; b) Velocity field and FE mesh. c) Normalized trajectories for several values of Stokes number, with table of trajectory slopes. d) Trajectory plotted with the same scale for both axes. Data: $\mathrm{c}=0.794$

$$
\begin{gathered}
\mu m, \mathrm{~b} / \mathrm{c}=0.5 ; \mathrm{h}=1.048 \mu \mathrm{m}, \mathrm{h} / \mathrm{c}=1.32, \rho_{p}=2 \mathrm{~g} / \mathrm{cm}^{3} \rho_{f}=1 \mathrm{~g} / \mathrm{cm}^{3}, \mu=1 \times 10^{-3} \mathrm{Pas}, x_{0}=10 \mu \mathrm{m}, \\
y_{0}=1.048 .
\end{gathered}
$$

Further, we investigate the particle size effect on trajectories and rotations, starting from nanoparticles with larger semiaxes of $10 \mathrm{~nm}$ to $700 \mathrm{~nm}$ and using the Stokes equations. The results are shown in Fig. 9a. Again, we obtain trajectories which demonstrate that particles tend to approach the wall, with the slope increasing with the particle size. However, the trajectory slope is small, as can be seen from table in Fig. 9a (trajectories are similar to those shown in Fig. 8d). Rotations expressed in terms of the axial coordinate are shown in Fig. 9b. It can be noted that the curves are close to straight lines, and that larger particles have slower rotations. 
a)

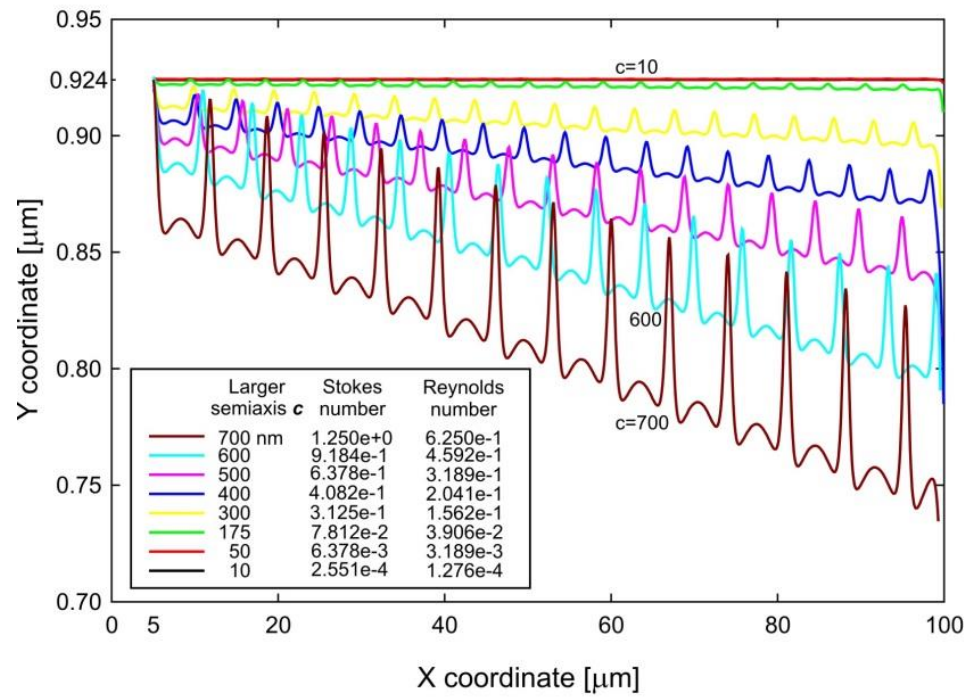

\begin{tabular}{|c|c|}
\hline $\begin{array}{c}\text { Larger } \\
\text { semiaxis } \\
\boldsymbol{c}[\mu \mathrm{m}]\end{array}$ & Angle $\left[{ }^{0}\right]$ \\
\hline 700 & -0.0614 \\
\hline 600 & -0.0506 \\
\hline 500 & -0.0374 \\
\hline 400 & -0.0145 \\
\hline 300 & -0.0115 \\
\hline 175 & -0.0013 \\
\hline 50 & $\sim 0.0$ \\
\hline 10 & $\sim 0.0$ \\
\hline
\end{tabular}

b)

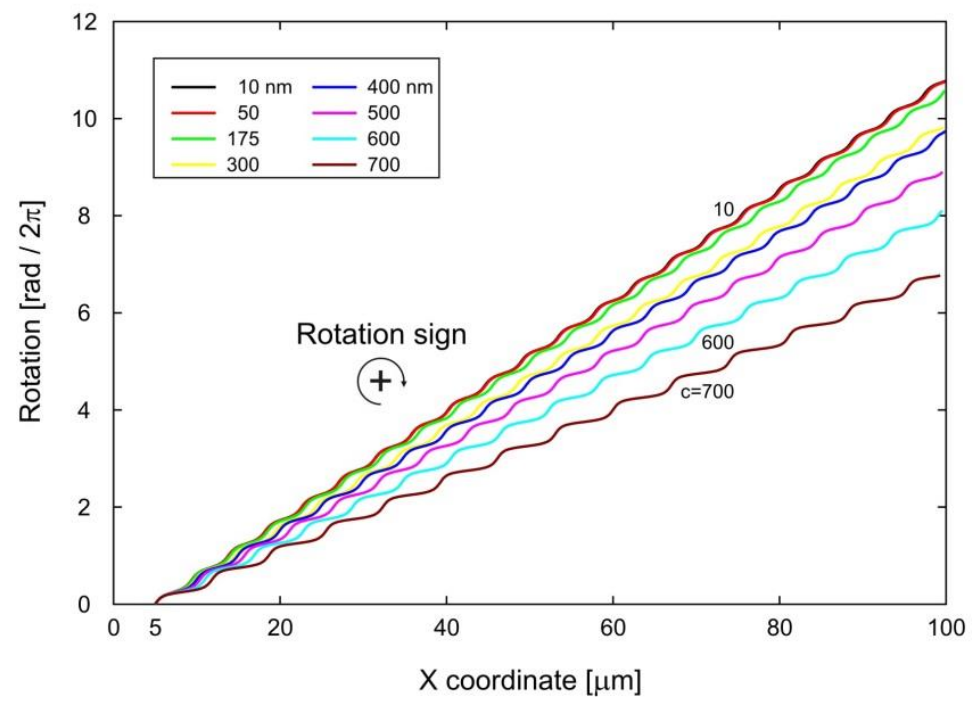

Fig. 9. Dependence of elliptical trajectories and rotations on particle size; Stokes model for fluid. a) Trajectories for several particle sizes, with the slope increasing with particle size; and table of slopes (maximum slope is $-0.0614^{\circ}$ for the largest particle). b) Rotations in terms of axial coordinate. Data: shear rate is $1.276 \mathrm{e}+6 \mathrm{~s}^{-1}$.

Finally, we investigate solutions obtained using the Navier-Stokes equations. We therefore consider the fluid-solid interaction as in the Stokes model, but now inertial forces of the fluid are included. In order to emphasize the difference between the Stokes and Navier-Stokes solutions we here take an elliptical particle with the semiaxis $\mathrm{c}=700 \mathrm{~nm}$, with an initial position $\mathrm{h} / \mathrm{c}=1.32$ (as in Stokes model), and increase the Re number from 0.625 (to compare with the Stokes model in Fig. 9) to 10 , by changing shear rate from $2.04 \mathrm{e}+6 \mathrm{~s}^{-1}$ to $2.04 \mathrm{e}+7 \mathrm{~s}^{-1}$. The results are given in Fig. 10. It can be seen that the trajectories have the opposite character with respect to the Stokes model - particles go away from the wall. Although the plotted trajectories give an impression of a large increase of distances from the wall, the mean slope of trajectories is only about $0.5 \mathrm{deg}$. 
Using the same scale for both axes $\mathrm{x}$ and $\mathrm{y}$, we obtain the true trajectories similar to that shown in Fig. 8d.

a)

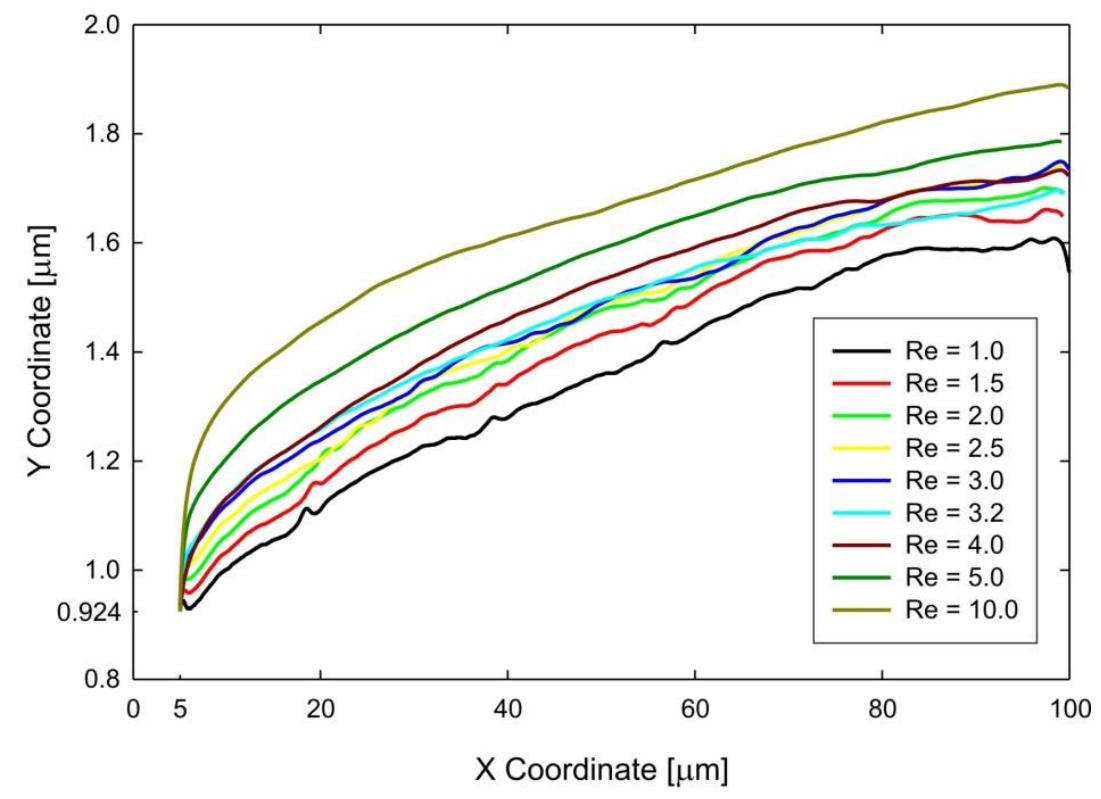

b)

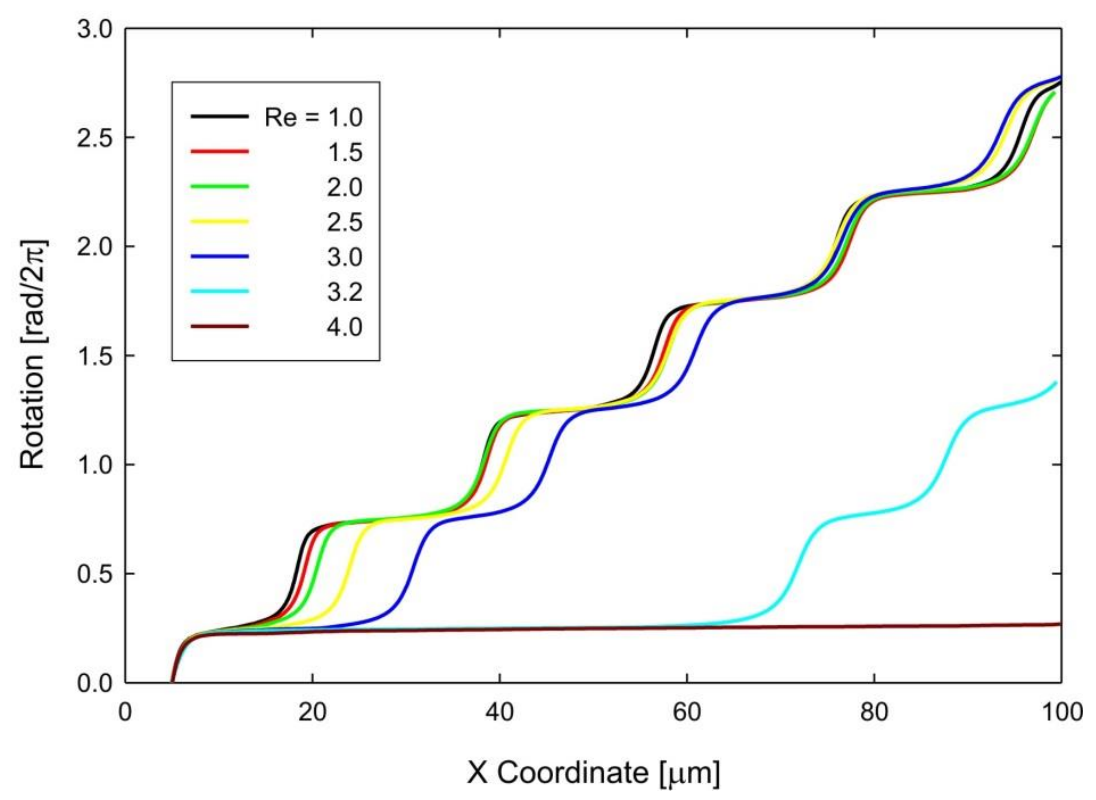

Fig. 10. Trajectories and rotations of elliptical particles in shear flow - based on solving the Navier-Stokes equations. a) Trajectories for several Re numbers, mean slope of trajectories is about $0.5 \mathrm{deg}$; b) Rotations in terms of axial displacement - increase in the shear rate leads to reorientation of the ellipse such that the larger axis becomes parallel to the wall. Data: semiaxis $\mathrm{c}=700 \mathrm{~nm}$; Re increased by changing shear rate from $2.04 \mathrm{e}+6 \mathrm{~s}^{-1}$ to $2.04 \mathrm{e}+7 \mathrm{~s}^{-1}$. 
It is also interesting to note the effect of Re number on rotation. The number of rotations in terms of the axial coordinate is shown in Fig. 10b. For $\mathrm{Re}=4$ or larger, the ellipse rotates for $90^{\circ}$ and continues in the configuration shown in the figure, with the larger axis aligned with the flow. For $\operatorname{Re}=3.2$, the ellipse rotates for $90^{\circ}$ and after some time starts to rotate with a rate similar to smaller Re numbers. The number of rotations of a circular particle with radius $\mathrm{R}=0.495 \mu \mathrm{m}$ is around 9 at coordinate $\mathrm{x}=100 \mu \mathrm{m}$, which is much larger than of the ellipse with the same area ( $c=0.7 \mu \mathrm{m}$, number of rotations 2.75 ; graphs of rotation vs. axial coordinate are not shown). The relation between number of rotations of circular and elliptical particles have the same character as for cases of motion within Poisseuille flow (Figure 7). Also, comparing the number of full rotations for a given particle (with $\mathrm{c}=700 \mathrm{~nm}$ ) in Figs. 9b and 10b, it can be seen that the Stokes model solution gives significantly larger rotation with respect to the Navier-Stokes model, hence inertial effects are significant for rotations.

\section{Conclusions}

This study offers an insight into motion of micron and sub-micron size particles in two flow conditions: Poiseuille flow in microchannels and shear (Couette) flow. The solutions are obtained by incorporating fluid-solid interaction via a strong coupling method and with a remeshing procedure. The authors have found that this methodology provides reliable results, demonstrated by good agreement with results from literature.

The following conclusions can be extracted from the presented results:

a) Trajectories of micro- and nano-particles within fluid flowing through microchannels are not significantly affected by the shape and size since they are close to being parallel to the wall of straight channels. In case of motion within channels with narrowing, trajectories of circular and elliptical particles are practically the same, even in case of presence of deformable disks; in that case, rotations of elliptical particles are slower than in the case of circular particles with the same cross-sectional area.

b) In shear flow, elliptical particle trajectories have a wavy character, with small amplitudes and very shallow average slopes, so that it can be considered that trajectories are practically parallel to the wall. Trajectories of circular particles are straight lines, with also very shallow slopes. Stokes equations for fluid give particle trajectories approaching the wall, while for Navier-Stokes equations we found that particles go away from the wall (but the change of distance from the wall is small). As in the case of Poiseuille flow, elliptical particles rotate much slower when compared to circular particles of the same cross-sectional area; rotations are slower when the Navier-Stokes model is used.

These findings can be useful for practical applications of micron and sub-micron particles transport in engineering, bioengineering and medicine.

Acknowledgements This work has been partially supported by the Methodist Research Institute, by the grants OI 174028 and III 41007 of the Serbian Ministry of Education and Science, and City of Kragujevac - Serbia. Authors also acknowledge partial supports from the following funding sources: the Ernest Cockrell Jr. Distinguished Endowed Chair (M.F.), US Department of Defense (W81XWH-09-1-0212) (M.F.), National Institute of Health (U54CA143837, U54CA151668) (M.F.). 
Извод

\title{
Нумеричка студија путања микро и нано делића различитих облика у флуидном току кроз мале канале
}

\author{
V. Isailovic ${ }^{1}$, M. Kojic ${ }^{1,2,3^{*}}$, M. Milosevic ${ }^{2}$, N. Filipovic ${ }^{1,4}$, N. Kojic ${ }^{5}$, A. Ziemys ${ }^{2}$, M. \\ Ferrari $^{2}$ \\ ${ }^{1}$ Метрополитен Универзитет Београд - Центар за истраживанје и развој Биоинжинјеринг \\ БиоИРЦ, Крагујевац, Србија \\ velibor@kg.ac.rs \\ ${ }^{2}$ The Houston Methodist Research Institute, Houston, TX, USA \\ mkojic42@gmail.com \\ ${ }^{3}$ Српска академија наука и уметности, Београд, Србија \\ mkojic42@gmail.com \\ ${ }^{4}$ Факултет техничких наука, Универзитет у Крагујевцу, Крагујевац, Србија \\ fica@kg.ac.rs \\ ${ }^{5}$ Center for Engineering in Medicine and Surgical Services, Massachusetts General Hospital, \\ Harvard Medical School, Boston, USA \\ * Главни аутор mkojic42@gmail.com
}

\section{Резиме}

Транспорт флуидом малих честица реда величине микрометра и мањих, јавља се у многим технолошким и биолошким системима. Димензије попречног пресека канала кроз које флуид тече се често крећу од неколико микрометара до неколико десетина микрометара. Циљ ове студије је да се истражи утицај облика микро и нано честица на њихове путање у случају када се оне транспортују унутар малих канала као што су крвни судови. Ефикасност терапија лековима који се транспортују помоћу честица значајно зависи од путања тих честица. Пожељно је да путање честица буду такве да се честице приближавају зидовима крвног суда, како би се повећала ефикасност терапије. Истражили смо кретање честица у каналима (цевима) за два физичка случаја: Поазјеово струјање, које је карактеристично за струјање у цевима, и струјање са смичућим профилом брзине. Струјање са смичућим профилом брзине је анализирано зато што карактер струјања флуида у близини зида у овим системима може бити апроксимиран смичућим струјањем, са линеарном променом брзине удаљавањем од зида. Овде смо истраживали путање честица различитих облика у 2Д струјању коришћењем методе коначних елемената (МКЕ), уз примену концепта јаког спрезања солид-флуид интеракције и поступка ажурирања мреже коначних елемената. Резултати дају увид у карактеристике кретања честица као што су путање и ротације при различитим условима струјања у каналима микронских димензија, укључујући струјање у присуству покретних деформабилних дискова. Показали смо да су путање честица у суштини паралелне зиду за различите услове, а да величина и облик честица не мењају знатно паралелну природу путања.

Кључне речи: солид-флуид интеракција, кретање честица, Поазјево струјање, струјање са смичућим профилом брзине, микро канали, мали крвни судови, метода коначних елемената 


\section{References}

Adriani G, Tullio MDd, Ferrari M, Hussain F, Pascazio G, Liu X, Decuzzi P. 2012. The preferential targeting of the diseased microvasculature by disk-like particles. Biomaterials 33:5504-5513.

Asmolov ES. 1999. The inertial lift on a spherical particle in a plane Poiseuille flow at large channel Reynolds number. J Fluid Mech.381:63-87.

Bathe KJ. 1996. Finite Element Procedures Englewood Cliffs, N.J.: Prentice-Hall, Inc.

Carlo DD, Irimia D, Tompkins RG, Toner M. 2007. Continuous inertial focusing, ordering, and separation of particles in microchannels. PNAS.104 18892-18897

Chun B, Ladda AJC. 2006. Inertial migration of neutrally buoyant particles in a square duct: An investigation of multiple equilibrium positions. Physcs of Fluids.18: 031704.

Decuzzi P, Lee S, Bhushan B, Ferrari M. 2005. A theoretical model for the margination of particles within blood vessels. Annals of Biomed Engrg.33:179-190.

Feng Z-G, Michaelides EE. 2003. Equilibrium position for a particle in a horizontal shear flow. Int J Multiphase Flow 29:943-957.

Ferrari M. 2005. Cancer nanotechnology: Opportunities and challenges. Nat Rev Cancer 5:161171.

Freeman B. 1985. The motion of rigid ellipsoidal particcles in slow flows. Technophysics.113:163-183.

Gavze E, Shapiro M. 1998. Motion of inertial spheroidal particles in a shear fow near a solid wall with special application to aerosol transport in microgravity. J Fluid Mech 371:59-79.

Gentile F, Chiappini C, Fine D, Bhavane RC, Peluccio MS, Cheng MM-C, Liu X, Ferrari M, Decuzzi P. 2008. The effect of shape on the margination dynamics of non-neutrally buoyant particles in two-dimensional shear flows. Journal of Biomechanics 41: 2312-2318.

Glowinski R, Pan TW, Hesla TI, Joseph DD, Periaux J. 2001. A fictitious domain approach to the direct numerical simulation of incompressible viscous flow past moving rigid bodies: application to particulate flow. J Comput Physics.169:363-426

Goano CD, Minev PD, Nandakumar K. 2003. A fictitious domain/finite element method for particulate flows. J Comput Physics.192:105-123.

Gutfinger C, Fichman M, Pnueli D. 1998. Effect of lift on the motion of aerosol particles. J Aerosol Sci 29:S1105-S1106.

Hu HH, Joseph DD, Crochet MJ. 1992. Direct simulation of fluid particle motions. Theoret Comput Fluid Dynamics.3:285-306.

Hu HH, Patankar NA, Zhu MY. 2001. Direct numerical simulations of fluid-solid systems using the arbitrary Lagrangian-Eulerian technique. J Comput Physics 169:427-462.

Isailovic V. 2012. Numerical modeling of motion of cells, micro- and nano- particles in blood vessels Belgrade: Metropolitan University.

Jayageeth C, Sharma VI, Singh A. 2009. Dynamics of short fiber suspensions in bounded shear flow. Int J Multiphase Flow.35:261-269.

Kojic M, Bathe KJ. 2005. Inelastic Analysis of Solids and Structures Heildelberg - Berlin: Springer-Verlag.

Kojic M, Filipovic N, Slavkovic R, Zivkovic M, Grujovic N. 1998, 2009. PAK-FS - Finite Element Program for Fluid Flow and Fluid-Solid Interaction Kragujevac, Serbia: University of Kragujevac and R\&D Center for Bioengineering, Kragujevac, Serbia.

Kojic M, Filipovic N, Stojanovic B, Kojic N. 2008. Computer Modeling in Bioengineering Theoretical Background, Examples and Software Chichester, England: John Wiley and Sons.

Kojic M, Milosevic M, Kojic N, Ferrari M, Ziemys A. 2013. Numerical modeling of diffusion in complex media with surface interaction effects. Contemporary Materials.2:153-166.

Kojic M, Ziemys A, Milosevic M, Isailovic V, Kojic N, Rosic M, Filipovic N, Ferrari M. 2011. Transport in biological systems. J Serbian Soc Comp Mechanics.Vol. 5 101-128. 
Lee S-Y, Ferrari M, PaoloDecuzzi. 2009. Design of bio-mimetic particles with enhanced vascular interaction. J Biomechanics.42:1885-1890.

Matas JP, Morris JF, Guazzelli E. 2004. Lateral forces on a sphere. Oil \& Gas Sc Technology Rev IFP.59 59-70.

Matas JP, Morris JF, Guazzelli E. 2009. Lateral force on a rigid sphere in large-inertia laminar pipe flow. J Fluid Mech. 621:59-67.

Mazutis L, Gilbert J, W.L. U, Weitz DA, Griffiths AD, Heyman JA. 2013. Single-cell analysis and sorting using droplet-based microfluidics. Nature protocols.8:870-891.

$\mathrm{Ng} \mathrm{BH}$, Kwan CC, Ding YL, Ghadiri M, Fan XF. 2007. Solids motion of calcium carbonate particles in a high shear mixer granulator: A comparison between dry and wet conditions. Powder Technology.177:1-11.

Nott PR, Brady JF. 1994. Pressure-driven flow of suspensions : simulation and theory. J Fluid Mech.275:157-199.

Patankar NA, Huang PY, Ko T, Joseph DD. 2001. Lift-off of a single particle in Newtonian and viscoelastic fluids by direct numerical simulation. J Fluid Mech 438:67-100.

Pozrikidis C. 2006a. Flipping of an adherent blood platelet over a substrate. J Fluid Mech.568:161-172.

Pozrikidis C. 2006b. Interception of two spheroidal particles in shear flow. J Non-Newtonian Fluid Mech.136:50-63.

Schindelin J, Arganda-Carreras I, Firse E, Kaynig V, Longair M, Pietzsch T, Preibisch S, Rueden C, Saalfeld S, Schmid B, et al. 9. Fiji: an open source platform for biological image analysis. Nature Methods.676-682.

Singh A, Nott PR. 2000. Normal stresses and microstructure in bounded sheared suspensions via Stokesian Dynamics simulations. J Fluid Mech.412:279-301.

Singh P, Hesla TI, Joseph DD. 2003. Distributed Lagrange multiplier method for particulate flows with collisions. Int J Multiphase Flow.29:495-509.

You CF, Li GH, Qi HY, Xu XC. 2004. Motion of micro-particles in channel flow. Atmospheric Environment 38:1559-1565.

Zhang L, Gerstenberger A, Wang X, Liu WK. 2004. Immersed finite element method. Comput Methods Appl Mech Engrg 193:2051-2067.

Zhou J, Papautsky I. 2013. Fundamentals of inertial focusing in microchannels. Lab Chip.13:1121-1132. 